\title{
Brachiaria Grass for Climate Resilient and Sustainable Livestock Production in Kenya
}

\author{
D. M. G. Njarui, M. Gatheru, and S. R. Ghimire
}

\section{Contents}

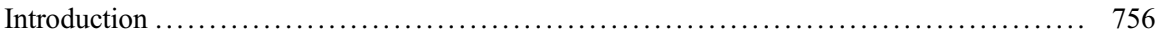

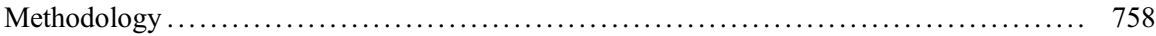

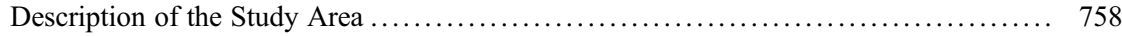

Brachiaria Grass Validation Trial ........................................... 759

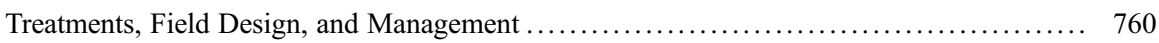

Data Collection and Statistical Analysis ...................................... 760

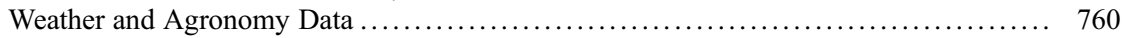

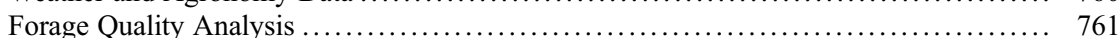

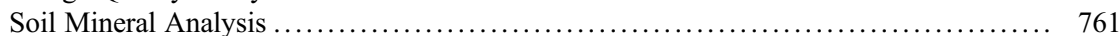

Participatory Evaluation of Brachiaria Grass Cultivars ......................... 761

On-Farm Evaluation of Brachiaria Grass Cultivars ............................ 762

Strategies Used to Upscale Brachiaria Grass Cultivars ......................... 762

Statistical Data Analysis ................................................ 763

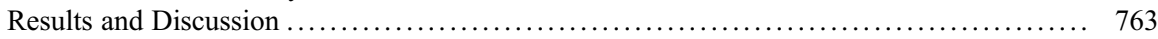

Brachiaria Grass Validation Trial ......................................... 763

Brachiaria Grass On-Farm Trials ...................................... 767

This chapter was previously published non-open access with exclusive rights reserved by the Publisher. It has been changed retrospectively to open access under a CC BY 4.0 license and the copyright holder is "The Author(s)". For further details, please see the license information at the end of the chapter.

D. M. G. Njarui $(\bowtie) \cdot$ M. Gatheru

Kenya Agricultural and Livestock Research Organization (KALRO), Katumani, Kenya e-mail: donaldnjarui@yahoo.com

S. R. Ghimire

The Biosciences eastern and central Africa - International Livestock Research Institute (BecA-ILRI) Hub, Nairobi, Kenya 
Participatory Selection of Brachiaria Grass Cultivars ......................... 768

Upscaling Brachiaria Grasses Cultivars .................................. 772

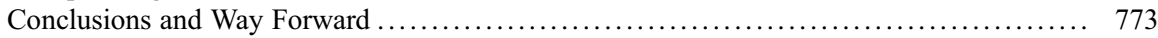

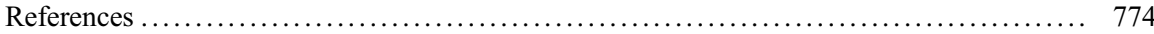

\section{Abstract}

Brachiaria grass is a "climate smart" forage that produces high amount of palatable and nutritious biomass for livestock and performs well in infertile soils, sequesters carbon in soil, and provides several environmental benefits. The objective of the study was to validate the productivity of Brachiaria grass and upscale the suitable cultivars for improved livestock feed resources in Kenya. We assume integrating Brachiaria grass into mixed crop-livestock system will enhance feed availability and livestock productivity, leading to increased food and nutrition security. Farmer participatory approach was adopted to evaluate and promote four Brachiaria grass (Brachiaria decumbens cv. Basilisk, B. brizantha cvs. Xaraes, Piata, and MG-4) in the Central Highland and Eastern Midland of Kenya. The extension/advisory approaches used to promote Brachiaria grass cultivars included field days, village knowledge centres, agricultural shows, posters, and linkages with other institutions through multi-actor platform established under the InnovAfrica project. Generally, Brachiaria grass cultivars were more productive than the control (Rhodes grass) in most harvests reaching peak of 5.1-7.7 t/ha in the fifth harvest. For Rhodes grass, DM was less than 4 t/ha in all harvest and died by sixth harvest. Similarly, based on farmers' evaluation using phenotypic traits, the Brachiaria grass cultivars had higher score than Rhodes grass except cv. Piata. The mean score ranged from 2.75 to 3.19 for Brachiaria cultivars, while for Rhodes the mean score was 2.63. Within 2 years of intervention, over 4000 farmers in the 2 project sites and additional 1500 farmers from other parts of the country have planted the Brachiaria grass. The demand for Brachiaria grass seeds is increasing due to benefits gained, e.g., increased milk production from dairy cattle fed on the grass. Our study will quantify the associated benefits from cultivation of Brachiaria grass with respect to a set of ecological, food and nutrition security, and social-economic indicators.

\section{Introduction}

There is wide empirical evidence that livestock plays an important economic role in Kenya. The livestock subsector contributes about $12 \%$ to the national Gross Domestic Product in the country (RoK 2019). Livestock serves multiple purposes that include food and nutritional security. Livestock is sold to generate income; provide manure and draft power for crop production, skins, and transport; and serve in social-cultural function and source of prestige within the pastoral society. The effects of climate change have challenged the sustainability of livestock 
sector. The changing pattern and frequency of extreme climatic conditions such as droughts and floods have great impacts on livestock and the associated livelihoods (Freier et al. 2012; Schilling et al. 2012). Extreme climatic events such as droughts and heavy rains are expected to become more frequent in the Horn of Africa and part of East Africa (Christensen et al. 2007; World Bank 2013). Climate change leads to reductions in livestock productivity by indirectly compromising the availability of forages (Martin et al. 2016). The impacts on forage availability and quality may include changes in herbage growth, changes in composition of vegetation, and overall changes in herbage quality (Thornton et al. 2009).

In the mixed crop-livestock production systems where dairy farming is practiced, several forage innovations have been in use to alleviate livestock feed shortage. Napier grass is the most widely cultivated forage in the humid and subhumid regions of Kenya, and over $90 \%$ of dairy farmers depend on it, but it is threatened by smut and stunting diseases. These diseases have been reported to cause damage ranging from $5 \%$ to $90 \%$ (Lusweti et al. 2004). There is need to introduce climate smart technologies to improve resilience and sustainable livestock systems to climate change. One option is the Brachiaria grass which is a "climate smart" and increases livestock productivity (Muinga et al. 2016; Ngila et al. 2016).

Brachiaria is one of the important tropical forage grasses of African origin. It is widely cultivated in South America, Australia, and East Asia and has demonstrated success in transformation of beef and dairy industries (Ghimire et al. 2015). The perennial Brachiaria grass species produce high tonnage of foliage biomass, possess large root systems, sequester carbon into soils, is adapted to drought and low fertility soils, and provide several environmental benefits and ecosystem services (Djikeng et al. 2014; Njarui et al. 2016).

Although native to Eastern and Central Africa, its use as livestock feed has been extremely limited in the region including Kenya. Improved Brachiaria grass cultivars identified in evaluations conducted in Eastern Midlands (EM) region of Kenya can bridge the gap on livestock feed scarcity. However, there is limited information available on the productivity of different Brachiaria cultivars in different agroecological zones (AEZ) of Kenya. For instance, only a limited number of farmers are aware on benefits of Brachiaria grass to livestock productivity. The dry matter (DM) yield of Brachiaria grass varies in different AEZ and is influenced by a range of factors including cultivars, moisture, soil fertility, pest and disease, and management options. To achieve a sustainable impact of Brachiaria grass in Kenyan livestock sector, a wide-scale adoption of this grass is necessary. This requires selection of right cultivars for a given production environment prior to integration in the farming system, and engaging farmers in the cultivar selection would be crucial for adoption and scaling of the technology. The objective of the study was to validate the productivity of Brachiaria grass and upscale the suitable cultivars for improved livestock feed resources in Kenya. 


\section{Methodology}

\section{Description of the Study Area}

The study was carried out in Kirinyaga County in Central Highlands $(\mathrm{CH})$ and Kangundo subcounty in EM (Fig. 1). These sites differ in agroecological characteristics and diversity in farming system. Brachiaria grass had been tested and found to be suitable in the EM and hence was upscaled among the smallholder crop-livestock farmers who keep dairy cattle for commercial production. We adopted farmer participatory approach to evaluate and promote Brachiaria technologies in the $\mathrm{CH}$ and EM of Kenya using a novel extension approach - i.e., the Village Knowledge Centre (VKC) supported by innovative institutional approach - multi-actor platforms (MAP) that was established and being operational under the InnovAfrica project (www.innovafrica.eu). On the other hand, Brachiaria grasses were evaluated in the $\mathrm{CH}$ since no research had been conducted on this grass in the region. The biophysical, farming system and other features of study sites are described below.

Kirinyaga County: Kirinyaga is one of the counties in the CH of Kenya. It is located between latitudes $0^{\circ} 1^{\prime}$ and $0^{\circ} 40^{\prime}$ South and longitudes $37^{\circ}$ and $38^{\circ}$ East and

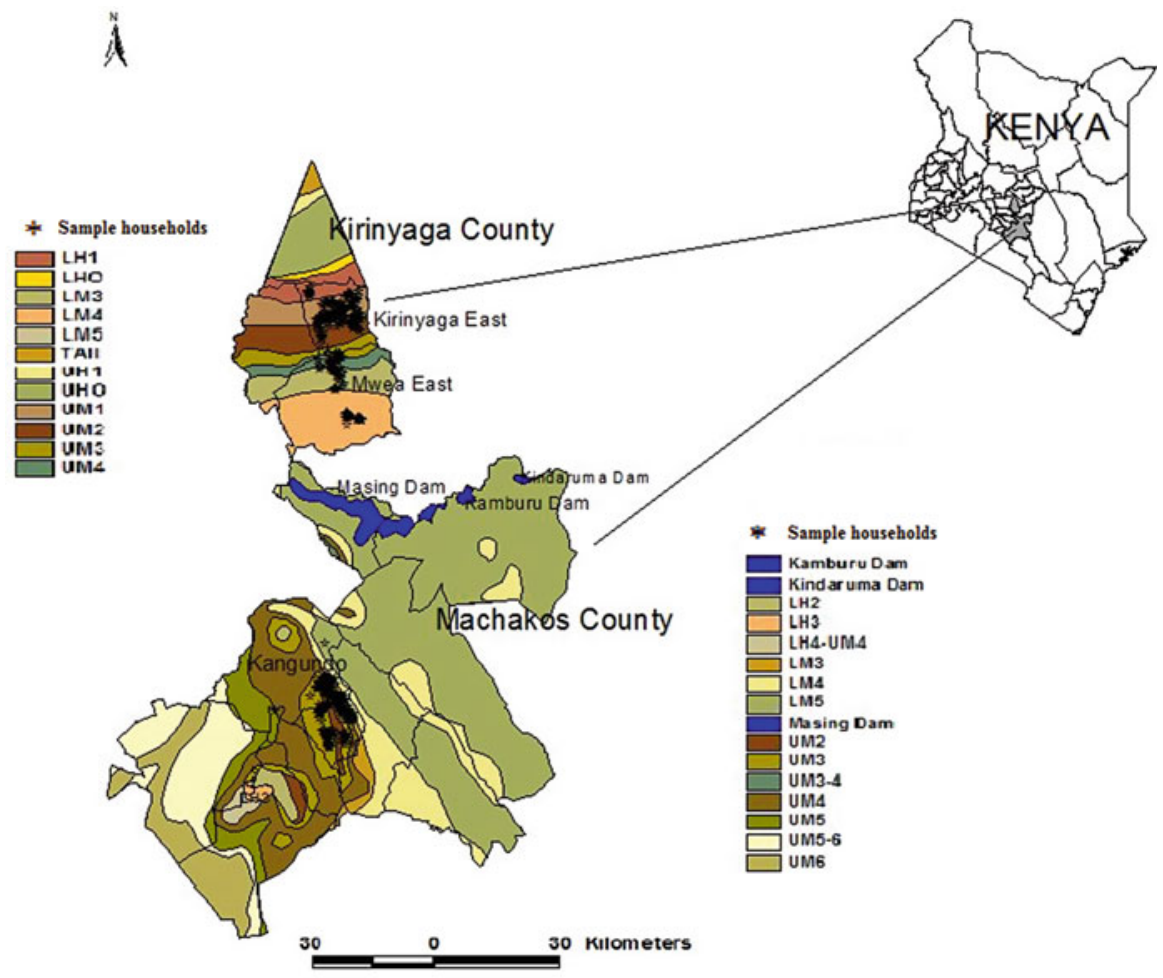

Fig. 1 Map showing project study sites 
covers an area of $1478 \mathrm{~km}^{2}$. The altitude ranges from 1200 to $1700 \mathrm{~m}$ above sea level (asl), but in the northern side, it rises to $5200 \mathrm{~m}$ at the top of Mt. Kenya. The major soil is Humic Nitosols (Jaetzold et al. 2006). According to 2009 census, the population stood at 528,054 persons comprising 154,220 households (KNBS 2010).

Rainfall is bimodal, the long rains occurring from March and May and the short rains from October to December with average annual rainfall from 1200 to $1500 \mathrm{~mm}$, which is well distributed and reliable for forage production. Temperature ranges from $12{ }^{\circ} \mathrm{C}$ to $27^{\circ} \mathrm{C}$ (Jaetzold et al. 2006). Farming is predominantly mixed crop-livestock system. The main cash crop are rice, tea, and coffee, while maize, beans, bananas, and sweet potatoes are the main food crops but are often sold to generate income. Major livestock are cattle, goats, sheep, and poultry. Dairy farming is an important enterprise and is based on exotic cattle and their crosses, mainly under stall feeding system. Napier grass is the main feed resource, while banana stems, sweet potatoes, and crop residues are fed during the dry season.

The Brachiaria grass validation trial was conducted at Kamweti Agricultural Training Centre (ATC) in Kirinyaga Country. Kamweti ATC lies on the southern slopes of Mt. Kenya at an altitude of $1755 \mathrm{~m}$ asl. The soil characteristics from samples taken $(0-30 \mathrm{~cm}$ depth) indicated that the texture of the soil was sandy clay, with average $\mathrm{pH}$ of 4.87 , total nitrogen content $(0.23 \%)$ and organic carbon about $2.5 \%$.

Kangundo subcounty: Kangundo, a subcounties of Machakos County, lies between latitudes $0^{\circ} 45^{\prime}$ and $1^{\circ} 31^{\prime}$ South and longitudes $36^{\circ} 45^{\prime}$ and $37^{\circ} 45^{\prime}$ East With altitude range of $800-1600 \mathrm{~m}$ asl. This subcounty has an area of $177 \mathrm{~km}^{2}$ with population of about 94,367 (KNBS 2010). The predominant soils are Luvisols, Acrisols, and Ferralsols derived from the Precambrian "basement-complex" rocks (Simpson et al. 1996). They are often shallow, contain low organic matter and high sand content (Kusewa and Guiragossion 1989), but are well drained.

Rainfall pattern is similar to Kirinyaga County but is lower and ranges from 800 to $1050 \mathrm{~mm}$ annually. Inter-seasonal rainfall variation is large with coefficient of variation of between $45 \%$ and $58 \%$ (Keating et al. 1992). Temperatures vary from $14{ }^{\circ} \mathrm{C}$ to $29^{\circ} \mathrm{C}$ with February and September being the hottest months and July and August the coolest months.

Maize is the most important cereal and is commonly intercropped with beans, cowpea, and pigeon pea. Coffee is an important cash crop in the Upper Midlands AEZ. The dairy cattle are mainly kept under stall feeding where feed is delivered. Improved forages such as Napier and Rhodes grass are planted but occupy only in a small proportion on the farm. Seasonal shortfall of feed resources is common due to prolonged drought and erratic rainfall and poor management of pastures.

\section{Brachiaria Grass Validation Trial}

The Brachiaria grass cultivars tested in this study were identified from an evaluation conducted on several accessions and cultivars in Kenya (Njarui et al. 2016). They were found to be productive and had positive responses to livestock productivity. The objective of the validation trial was to evaluate the growth and productivity of 
best bet Brachiaria grass cultivars. The validation trials were managed by researchers and were conducted at Kamweti ATC involving farmers.

\section{Treatments, Field Design, and Management}

Four best bet Brachiaria grass cultivars, namely, Brachiaria decumbens cv. Basilisk, $B$. brizantha cvs. MG-4, Piata, and Xaraes, were compared with Rhodes grass - a commonly cultivated grass in the region. The treatments were arranged in a randomized block design with three replications in plot sizes of $4 \mathrm{~m} \times 5 \mathrm{~m}$ with $1 \mathrm{~m}$ alley between plots. Ten rows were planted in each plot at interrows spacing of $50 \mathrm{~cm}$. The land was ploughed and harrowed to a fine tilth before planting the seeds. The seeds were drilled by hand along shallow furrows of about $0.5-1 \mathrm{~cm}$ deep at a rate of $5 \mathrm{~kg} / \mathrm{ha}$ for all the grasses and covered lightly with soil. Triple Super Phosphate fertilizer (TSP $46 \% \mathrm{P}_{2} \mathrm{O}_{5}$ ) was applied in the planting furrows prior to sowing the seeds at a rate of $40 \mathrm{~kg} / \mathrm{ha}$ P.

The trial was established in March 2018, during the long rains (LR) season (March-May). A standardization cut was made after the end of first wet season in June 2018 in all plots to stimulate uniform plant growth. Calcium ammonium nitrate $(\mathrm{CAN}, 26 \% \mathrm{~N})$ was applied at a rate of $50 \mathrm{~kg} \mathrm{~N} / \mathrm{ha} /$ season and commenced after the standardization cut. The fertilizer was broadcasted in the plots and covered slightly using hand hoes, approximately 1 week after onset of rainy season. The plots were kept weed-free by weeding using handheld hoes until the grass were fully established.

\section{Data Collection and Statistical Analysis}

\section{Weather and Agronomy Data}

Rainfall data was recorded from the weather station near the experimental plots. The first wet seasons (LR 2018) was regarded as the establishment phase and subsequent seasons as production phase. During the production phase, the data collected included plant numbers, tiller numbers, plant height, pests and diseases damage, and dry matter (DM) yield at 8 weeks interval. Numbers of plants were determined by counting plants within a $1 \mathrm{~m}^{2}$ frame, randomly placed over two central rows. Tiller numbers and plant height were recorded for four plants in the same quadrat. Plant height was measured for from ground to the tip of plant. Pests and diseases damage were rated on a $1-5$ scale; where $0=$ no damage and $5=$ highest damage. For dry matter (DM) yield determination, an area of $2 \mathrm{~m} \times 2 \mathrm{~m}$ fixed quadrat was sampled by cutting the plants to around $5 \mathrm{~cm}$ stubble height using handheld sickles. The fresh materials were weighed, a subsample taken where necessary, and dried at $105{ }^{\circ} \mathrm{C}$ for $48 \mathrm{~h}$. The rainfall at Kamweti ATC from January 2018 to December 2019 is given in Fig. 2. The total monthly rainfall in March and April 2018 was greater than 2019 rainfall recorded during the same months, whereas October and December rainfall was higher in 2019 than in 2018. 


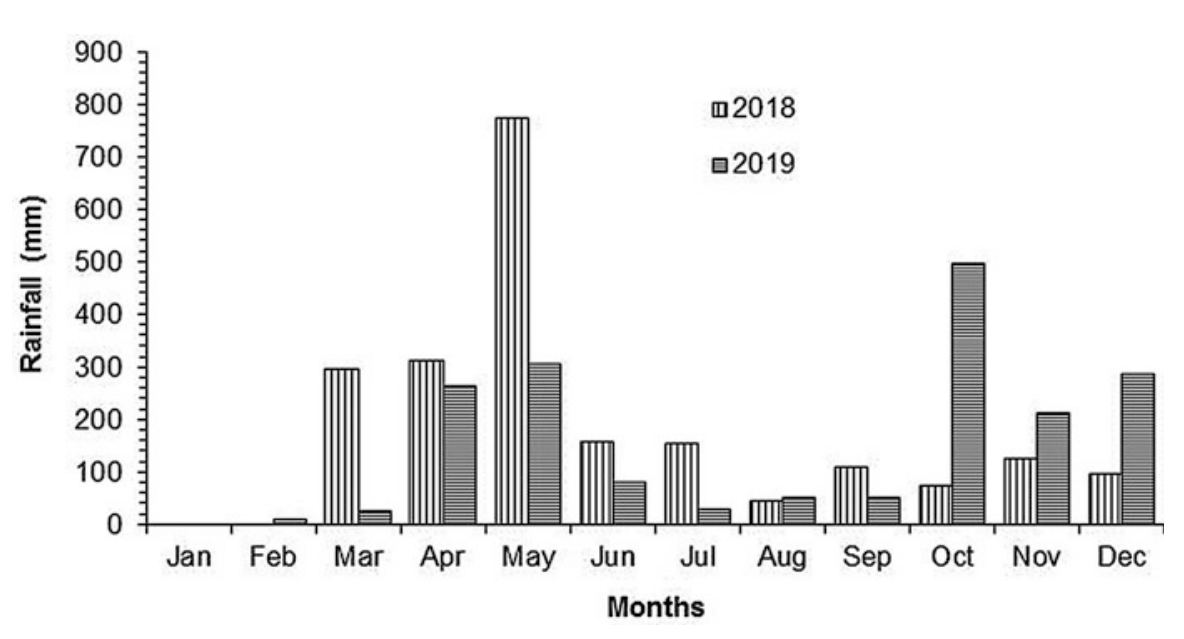

Fig. 2 Monthly rainfall during the experimental period, March 2018-December 2019 at Kamweti ATC, Kenya

\section{Forage Quality Analysis}

The herbage was analyzed for phosphorus, calcium, crude protein (CP), fibers, lignin, and ash for samples harvested in July 2019. The samples were dried at $65^{\circ} \mathrm{C}$ in an oven to a constant weight and then ground with a hammer mill fitted with a $1 \mathrm{~mm}$ sieve, and about $200 \mathrm{~g}$ was preserved for analysis. Ash was determined by heating the samples at $550{ }^{\circ} \mathrm{C}$ for $8 \mathrm{~h}$ in a muffle furnace. Crude protein was determined using Micro-Kjeldahl according to the method of Association of Official Analytical Chemists (AOAC) (1990). The neutral detergent fiber (NDF), acid detergent fiber (ADF), and acid detergent lignin (ADL) were determined using the Ankom method of Van Soest et al. (1991).

\section{Soil Mineral Analysis}

The soil samples were taken from a depth of 0 to $30 \mathrm{~cm}$ in each grass plot and airdried. Analysis was carried out for organic carbon (OC), total N, K available P, and $\mathrm{pH}$. Soil $\mathrm{pH}$ was measured in water (soil/water ratio of $1: 2.5$ ). The $\mathrm{N}$ was determined following the Micro-Kjeldahl method after Bremner and Keeney (1965), while P was measured by ascorbic acid method (Watanabe and Olsen 1965). The total OC and $\mathrm{K}$ were measured according to methods described by Okalebo et al. (2002).

\section{Participatory Evaluation of Brachiaria Grass Cultivars}

The criterion for evaluation of the Brachiaria grasses was developed through a focus group discussion of 26 farmers randomly selected from the region. Scientists and 
extension officers guided the farmers. A pairwise ranking matrix was used to rank the listed plant attributes in their order of importance which were then applied in the Brachiaria evaluation process. At the end of wet season, 72 farmers (26 females, 46 males) participated in the evaluation of the Brachiaria grass cultivars and Rhodes grass in the validation trial established at Kamweti ATC. The field assessment was based on grass phenotypic traits (visual herbage production, tillering capacity, height, hairiness, and easy to cut). For each trait, farmers recorded their individual scores for each individual grass cultivars in an evaluation form using a Likert scale of $1-4$, where, $1=$ poor, $2=$ average, $3=$ good and $4=$ very good.

\section{On-Farm Evaluation of Brachiaria Grass Cultivars}

Farmers who had previously participated in the project household baseline survey in Kangundo subcounty and Kirinyaga County were selected for Brachiaria grass on-farm trials. The criteria for selection of farmers were based on ownership of dairy cattle, willingness to participate in data collection, and ability of farmers to establish at least 0.1 ha of Brachiaria grass. The farmers were trained on establishment, management, and harvesting of the grasses. Individual farmers were provided with seeds of two cultivars (either Piata, Xaraes, or Basilisk). A total of 84 and 74 farmers received Brachiaria seeds in Kangundo subcounty and Kirinyaga County, respectively. Only 16 farmers were monitored in each site, and a farmer was considered as a replication. The land was prepared using local practices and sown in March and April 2018. Close supervision and monitoring was undertaken through joint action with farmers, extension, and researchers. A range of data was collected for assessment of ecological, food and nutrition security, and social-economic impact. For the ecological impact, the data collected includes Brachiaria biomass yield, soil organic carbon, effect of Brachiaria on milk production, and acreage under Brachiaria, while for the food and nutrition security impact, the data include availability of milk, level of consumption of milk, and dietary diversity. For the social-economic impact, the data collected include people aware of the technology, people growing Brachiaria, income from Brachiaria, and milk sales.

\section{Strategies Used to Upscale Brachiaria Grass Cultivars}

Different extension and advisory services (EAS) have been used to upscale the suitable Brachiaria grass cultivars in Kangundo and Kirinyaga counties and other areas in Kenya. Some of the EASs include VKC, field days, agricultural shows, posters, and linkages with other institutions with support of multi-actor platform. $\mathrm{VKC}$ is a digital-based system linking farming communities with shared interests through smart phones and social media platforms such as WhatsApp. The VKC has been adopted to disseminate technology. The process involved sensitizing farmers on benefits of the grass, providing information on planting, management, and 
harvesting followed by seed distribution. Each farmer was provided with seeds of two Brachiaria cultivars (40 $\mathrm{g}$ of each cultivar) enough to cover an area of $160 \mathrm{~m}^{2}$.

\section{Statistical Data Analysis}

From the validation trial only data on plant tillers, height and dry matter yield were analyzed at each harvest. Likewise the values for forage quality were also statistically evaluated. The participatory evaluation scores from each farmer were entered in Microsoft Excel spreadsheet and a mean score for each criterion calculated for each grass cultivar by gender. The data were subjected to Analysis of Variance (ANOVA) using the statistical software GenStat 15 for windows (VSN International Ltd 2013). And where significant differences occurred, the means were separated using the Fisher's protected least significant difference (LSD) test at $\mathrm{p}<0.05$.

\section{Results and Discussion}

\section{Brachiaria Grass Validation Trial}

\section{(i) Plant Height}

Table 1 shows the mean plant height of four Brachiaria grass cultivars and Rhodes grass. Plant height at each harvest period varied among the grass cultivars and showed significant differences $(\mathrm{p}<0.05)$. Rhodes grass was taller than all the Brachiaria cultivars in the first three harvests and in the

Table 1 Mean plant height (cm) of four Brachiaria grass cultivars and Rhodes grass (at 8 weeks cutting interval) at Kamweti ATC, Kenya

\begin{tabular}{|c|c|c|c|c|c|c|}
\hline \multirow[b]{3}{*}{ Grass cultivars } & \multicolumn{2}{|l|}{2018} & \multicolumn{4}{|l|}{2019} \\
\hline & $\begin{array}{l}\text { Harvest } \\
1 \\
\end{array}$ & $\begin{array}{l}\text { Harvest } \\
2\end{array}$ & $\begin{array}{l}\text { Harvest } \\
3\end{array}$ & $\begin{array}{l}\text { Harvest } \\
4\end{array}$ & $\begin{array}{l}\text { Harvest } \\
5\end{array}$ & $\begin{array}{l}\text { Harvest } \\
6 \\
\end{array}$ \\
\hline & 29 Sept & $20 \mathrm{Nov}$ & 15 Jan & 12 Mar & 4 July & 22 Aug \\
\hline $\begin{array}{l}\text { Brachiaria decumbens } \\
\text { cv. Basilisk }\end{array}$ & $21.8^{\mathrm{B}}$ & $31.5^{\mathrm{B}}$ & $18.4^{\mathrm{B}}$ & $5.7^{\mathrm{A}}$ & $63.9^{\mathrm{B}}$ & $9.2^{\mathrm{A}}$ \\
\hline $\begin{array}{l}\text { Brachiaria brizantha } \mathrm{cv} \text {. } \\
\text { MG-4 }\end{array}$ & $18.5^{\mathrm{B}}$ & $37.3^{\mathrm{B}}$ & $18.5^{\mathrm{B}}$ & $7.2^{\mathrm{A}}$ & $75.4^{\mathrm{B}}$ & $8.9^{\mathrm{A}, \mathrm{B}}$ \\
\hline $\begin{array}{l}\text { Brachiaria brizantha } \mathrm{cv} \text {. } \\
\text { Piata }\end{array}$ & $13.5^{\mathrm{B}}$ & $43.0^{\mathrm{B}}$ & $11.0^{\mathrm{B}}$ & $7.0^{\mathrm{A}}$ & $27.9^{\mathrm{C}}$ & $6.4^{\mathrm{C}}$ \\
\hline $\begin{array}{l}\text { Brachiaria brizantha } \mathrm{cv} . \\
\text { Xaraes }\end{array}$ & $12.5^{\mathrm{B}}$ & $35.5^{\mathrm{B}}$ & $11.0^{\mathrm{B}}$ & $5.2^{\mathrm{A}}$ & $24.6^{\mathrm{C}}$ & $7.2^{\mathrm{B}, \mathrm{C}}$ \\
\hline $\begin{array}{l}\text { Rhodes grass cv. KAT } \\
\text { R3 (control) }\end{array}$ & $48.6^{\mathrm{A}}$ & $86.7^{\mathrm{A}}$ & $55.0^{\mathrm{A}}$ & $7.6^{\mathrm{A}}$ & $103.6^{\mathrm{A}}$ & $-{ }^{\mathrm{a}}$ \\
\hline $\operatorname{LSD}(p<0.05)$ & 13.1 & 12.3 & 14.2 & N.S. ${ }^{b}$ & 17.3 & 1.9 \\
\hline
\end{tabular}

Means with different superscript in the same column differ significantly at $\mathrm{P}<0.05$

${ }^{a}$ Rhodes grass dried therefore no plants were measured

${ }^{\mathrm{b}}$ N.S. not significant 
fifth harvest, but in the fourth harvest, there was no significant difference among grass cultivars tested (Table 1). Lack of significance difference among the grasses in the fourth harvest was mainly due to poor rainfall experienced during the growing period, which reduced the growth of all grasses. Similarly, the low plant height in sixth harvest was attributed to low rainfall and low temperatures in 2019 (see Fig. 2)

(ii) Tiller Numbers

All the Brachiaria cultivars had higher tiller numbers than Rhodes grass at all harvests (Table 2). Xaraes recorded the highest number of tillers in most of the harvests. Tiller numbers increased from less than 100 tillers/plant at first harvest to greater than 120 tillers/plant in the fourth harvest for all the Brachiaria cultivars and Rhodes and declined in subsequent harvest except for Basilisk which increased slightly in fifth harvest. Brachiaria forms a massive root development, and hence nutrient uptake is likely to be high allowing the plant to continue increase in tillers. Reduce tillers number in fifth and sixth harvest were attributed to low rainfall and temperatures (see Fig. 2). The higher tillering ability of Brachiaria grass than Rhodes grass is due to difference in growth habit where Brachiaria forms rhizomes, while Rhodes grass spreads by stolon. Moreover, number of tillers is an indicator of resource use efficiency and increases the chances of survival and influences herbage yield (Laidlaw $2005)$ if water and nutrients are not limiting.

(iii) Dry Matter Yield

Six harvests for the DM yield were conducted during the production phase (Fig. 3a-f). There were no significant differences $(\mathrm{p}>0.05)$ on DM yield among the Brachiaria cultivars and Rhodes grass in the first three harvests and

Table 2 Mean number of tillers/plant of four Brachiaria grass cultivars and Rhodes grass (at 8 weeks cutting interval) at Kamweti ATC, Kenya

\begin{tabular}{|c|c|c|c|c|c|c|}
\hline \multirow[b]{3}{*}{ Grass cultivars } & \multicolumn{2}{|l|}{2018} & \multicolumn{4}{|l|}{2019} \\
\hline & $\begin{array}{l}\text { Harvest } \\
1\end{array}$ & $\begin{array}{l}\text { Harvest } \\
2\end{array}$ & $\begin{array}{l}\text { Harvest } \\
3\end{array}$ & $\begin{array}{l}\text { Harvest } \\
4\end{array}$ & $\begin{array}{l}\text { Harvest } \\
5\end{array}$ & $\begin{array}{l}\text { Harvest } \\
6\end{array}$ \\
\hline & 29 Sept & $20 \mathrm{Nov}$ & $15 \mathrm{Jan}$ & $12 \mathrm{Mar}$ & 4 July & $22 \mathrm{Aug}$ \\
\hline $\begin{array}{l}\text { Brachiaria decumbens } \\
\text { cv. Basilisk }\end{array}$ & $83.3^{\mathrm{A}, \mathrm{B}}$ & $116.3^{\mathrm{A}}$ & $127.7^{\mathrm{A}}$ & $140.3^{\mathrm{B}}$ & $163.3^{\mathrm{A}}$ & $137.3^{\mathrm{A}}$ \\
\hline $\begin{array}{l}\text { Brachiaria brizantha } \\
\text { cv. MG-4 }\end{array}$ & $89.3^{\mathrm{A}, \mathrm{B}}$ & $95.3^{\mathrm{A}}$ & $121.3^{\mathrm{A}}$ & $126.0^{\mathrm{B}}$ & $110.5^{\mathrm{B}}$ & $102.4^{\mathrm{A}}$ \\
\hline $\begin{array}{l}\text { Brachiaria brizantha } \\
\text { cv. Piata }\end{array}$ & $72.7^{\mathrm{B}, \mathrm{C}}$ & $78.7^{\mathrm{A}}$ & $142.7^{\mathrm{A}}$ & $151.7^{\mathrm{B}}$ & $131.1^{\mathrm{A}, \mathrm{B}}$ & $120.8^{\mathrm{A}}$ \\
\hline $\begin{array}{l}\text { Brachiaria brizantha } \\
\text { cv. Xaraes }\end{array}$ & $103.0^{\mathrm{A}}$ & $108.7^{\mathrm{A}}$ & $156.3^{\mathrm{A}}$ & $183.3^{\mathrm{A}}$ & $167.5^{\mathrm{A}}$ & $184.5^{\mathrm{A}}$ \\
\hline $\begin{array}{l}\text { Rhodes grass cv. KAT } \\
\text { R3 (control) }\end{array}$ & $46.7^{\mathrm{C}}$ & $34.7^{\mathrm{B}}$ & $45.7^{\mathrm{B}}$ & $48.7^{\mathrm{C}}$ & $31.4^{\mathrm{C}}$ & $-{ }^{\mathrm{a}}$ \\
\hline $\operatorname{LSD}(\mathrm{p}<0.05)$ & 30.3 & 43.5 & 55.3 & 29.9 & 46.5 & N.S. ${ }^{b}$ \\
\hline
\end{tabular}

Means with different superscript in the same column differ significantly at $\mathrm{P}<0.05$

${ }^{\text {a }}$ Rhodes grass dried therefore no plants were measured

${ }^{\mathrm{b}}$ N.S. not significant 

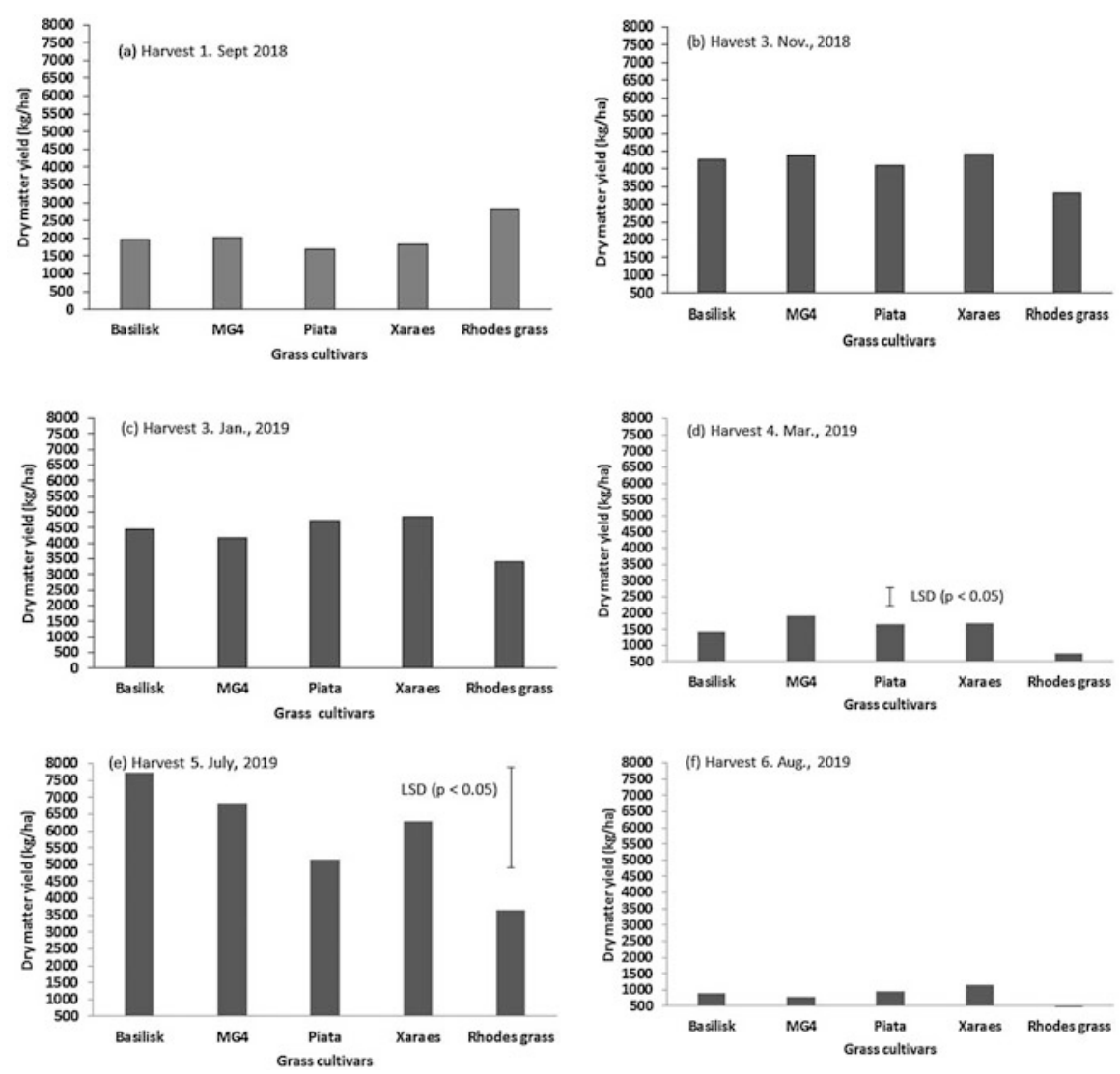

Fig. 3 Dry matter yield of four Brachiaria grass cultivars and Rhodes grass harvested every 8 weeks at Kamweti ATC, Kenya

sixth harvest. Significant $(\mathrm{p}<0.05)$ difference in yield was recorded in the fourth (Fig. 3d) and fifth harvests (Fig. 3e). In the fourth harvest, all Brachiaria cultivars outyielded Rhodes grass, but yields were not significant different among themselves (Fig. 3). Similar studies by Nyambati et al. (2016) in an area that has unimodal rainfall pattern showed no significance difference among the same Brachiaria cultivars, but their yields were higher than those of Rhodes grass. However, in the fifth harvest, only Basilisk had higher $(\mathrm{P}<0.05) \mathrm{DM}$ yield (7.7 t/ha) than Rhodes grass (3.6 t/ha) but did not differ significantly with the other Brachiaria grass cultivars. Generally, Brachiaria yields were relatively higher in the second (4.1-4.4 t/ha), third (4.1-4.8 t/ha), and reached peak in the fifth (5.1-7.7 t/ha) harvests, and this was attributed to moisture availability. The first harvest (Fig. 3a) was conducted during the long dry season, while the fourth (Fig. 3d) was carried out toward the end of the short dry season. The second and third harvest was conducted during the wet season. The DM yields were appreciably higher than yield recorded by Njarui et al. (2016) in EM. 
Table 3 Chemical composition (\% of DM) of Brachiaria grass cultivars and Rhodes grass harvested at Kamweti ATC, Kenya

\begin{tabular}{|c|c|c|c|c|c|c|c|}
\hline Grass cultivars & Calcium & Phosphorus & $\mathrm{CP}$ & $\mathrm{ADF}$ & NDF & ADL & Ash \\
\hline $\begin{array}{l}\text { Brachiaria } \\
\text { decumbens cv. } \\
\text { Basilisk }\end{array}$ & $0.15^{\mathrm{A}}$ & $0.37^{\mathrm{A}}$ & $11.60^{\mathrm{A}}$ & $41.49^{\mathrm{B}}$ & $\begin{array}{l}67.21^{\mathrm{B}}, \\
\mathrm{C}\end{array}$ & $6.94^{\mathrm{B}}$ & $9.81^{\mathrm{B}}$ \\
\hline $\begin{array}{l}\text { Brachiaria } \\
\text { brizantha } \mathrm{cv} . \\
\text { MG-4 }\end{array}$ & $0.16^{\mathrm{A}}$ & $0.24^{\mathrm{A}}$ & $11.60^{\mathrm{A}}$ & $40.40^{\mathrm{B}}$ & $\begin{array}{l}67.37^{\mathrm{B}}, \\
\mathrm{C}\end{array}$ & $\begin{array}{l}7.05^{\mathrm{A}} \\
\mathrm{B}\end{array}$ & $9.62^{\mathrm{B}}$ \\
\hline $\begin{array}{l}\text { Brachiaria } \\
\text { brizantha } \mathrm{cv} . \\
\text { Piata }\end{array}$ & $0.13^{\mathrm{A}}$ & $0.53^{\mathrm{A}}$ & $11.73^{\mathrm{A}}$ & $36.82^{\mathrm{C}}$ & $\begin{array}{l}65.02^{C,} \\
D\end{array}$ & $6.00^{\mathrm{B}}$ & $9.54^{\mathrm{B}}$ \\
\hline $\begin{array}{l}\text { Brachiaria } \\
\text { brizantha } \mathrm{cv} . \\
\text { Xaraes }\end{array}$ & $0.12^{\mathrm{A}}$ & $0.38^{\mathrm{A}}$ & $12.16^{\mathrm{A}}$ & $38.16^{\mathrm{C}}$ & $64.58^{\mathrm{D}}$ & $5.90^{\mathrm{B}}$ & $11.0^{\mathrm{A}}$ \\
\hline $\begin{array}{l}\text { Rhodes grass cv. } \\
\text { KAT R3 (control) }\end{array}$ & $0.18^{\mathrm{A}}$ & $0.34^{\mathrm{A}}$ & $10.19^{\mathrm{A}}$ & $44.86^{\mathrm{A}}$ & $71.40^{\mathrm{A}}$ & $8.61^{\mathrm{A}}$ & $7.87^{\mathrm{C}}$ \\
\hline $\operatorname{LSD}(\mathrm{P}<0.05)$ & N.S. ${ }^{a}$ & N.S. & N.S. & 1.94 & 2.60 & 1.39 & 0.93 \\
\hline CV (\%) & 6.5 & 4.9 & 2.1 & 2.6 & 2.1 & 10.7 & 5.2 \\
\hline
\end{tabular}

$C P$ crude protein, $A D F$ acid detergent fiber, $N D F$ neutral detergent fiber, $A D L$ acid detergent lignin Means with different superscript in the same column differ significantly at $\mathrm{P}<0.05$

${ }^{a} N . S$. not significant

\section{(iv) Forage Quality Composition}

The result of forage quality analysis is presented in Table 3. The calcium, phosphorus, and CP content were not significantly different among the tested grasses. Significant differences were recorded in ADF, NDF, ADL, and ash content. Rhodes grass had higher ADF and NDF than Brachiaria grass cultivars, while the ADL content did not differ from that of MG-4. Xaraes had the highest ash content (11\%), and the Rhodes grass had the lowest. However, all Brachiaria cultivars contained more CP than those reported from the Eastern Midland (7-10\%) by Njarui et al. (2016) but were lower than that reported from a similar region $-\mathrm{CH}(12-15 \%)$ by Nyambati et al. (2016). The lower CP content from this study was attributed to difference in the sampling time as the grasses were harvested during the dry season and growth was poor. Nevertheless, $\mathrm{CP} \geq 11 \%$ during the dry season is an indication that Brachiaria can provide good quality feed in $\mathrm{CH}$. All the Brachiaria met the minimum level of $\mathrm{CP}$ required for ruminant maintenance $(7 \%)$ and milk production $(11 \%)$. Moreover, the NDF was below $72 \%$, above which generally decreases DM intake. All the Brachiaria cultivars had lower ash content (12-15\%) than those reported by Njarui et al. (2016).

(v) Soil Nutrients

There was no statistical significance difference $(\mathrm{p}>0.05)$ on soil properties $(\mathrm{pH}, \mathrm{N}$, org $\mathrm{C}, \mathrm{P}$, and $\mathrm{K})$ among the tested Brachiaria grass cultivars and the Rhodes grass (Table 4). However, the total N (0.20-0.21\%) and organic carbon contents $(2.2-2.3 \%)$ in all Brachiaria cultivars were higher than the Rhodes 
Table 4 Effects of Brachiaria grass cultivars and Rhodes grass on soil $\mathrm{pH}$, organic carbon, and nutrients (nitrogen, phosphorus, and potassium), 18 months after planting

\begin{tabular}{l|l|l|l|l|l}
\hline Grass cultivars & $\begin{array}{l}\text { Soil } \mathrm{pH}(1: 2.5 \\
\left.\text { soil: } \mathrm{H}_{2} 0\right)\end{array}$ & $\begin{array}{l}\text { Nitrogen } \\
(\%)\end{array}$ & $\begin{array}{l}\text { Org. } \\
\text { carbon } \\
(\%)\end{array}$ & $\begin{array}{l}\text { Phosphorus } \\
(\mathrm{ppm})\end{array}$ & $\begin{array}{l}\text { Potassium } \\
(\mathrm{me} \%)\end{array}$ \\
\hline $\begin{array}{l}\text { Brachiaria } \\
\text { decumbens cv. } \\
\text { Basilisk }\end{array}$ & 4.84 & 0.21 & 2.28 & 20.0 & 0.09 \\
\hline $\begin{array}{l}\text { Brachiaria brizantha } \\
\text { cv. MG-4 }\end{array}$ & 4.89 & 0.21 & 2.34 & 18.3 & 0.11 \\
\hline $\begin{array}{l}\text { Brachiaria brizantha } \\
\text { cv. Piata }\end{array}$ & 4.74 & 0.20 & 2.29 & 15.0 & 0.09 \\
\hline $\begin{array}{l}\text { Brachiaria brizantha } \\
\text { cv. Xaraes }\end{array}$ & 5.01 & 0.21 & 2.33 & 21.7 & 0.09 \\
\hline $\begin{array}{l}\text { Rhodes grass cv. } \\
\text { KAT R3 (control) }\end{array}$ & 4.91 & 0.16 & 1.74 & 20.0 & 0.11 \\
\hline LSD (P < 0.05) & N.S. & N.S. & N.S. & N.S. & N.S. \\
\hline CV (\%) & 3.6 & 13.9 & 15.4 & 22.3 & 15.9 \\
\hline
\end{tabular}

${ }^{\mathrm{a} N}$.S. not significant

grass. The org $\mathrm{C}$ contents in the Brachiaria fields will improve the organic matter content of the soils, which in turn will enhance soil fertility and increase productivity. This makes Brachiaria grass suitable for adaptation and mitigation measures to climate change effects in Kenya and possibly in other subSaharan African countries. However, the effect of Brachiaria on soil $\mathrm{pH}$ would require relatively a longer period.

\section{Brachiaria Grass On-Farm Trials}

The mean DM yield of Brachiaria grass cultivar in Kirinyaga and Kangundo is given in Table 5. There were no statistical significant differences $(\mathrm{p}>0.05)$ on DM yield among the Brachiaria cultivars grass within and between sites. Of the 16 farms monitored in each site, there were large variations in yield for each Brachiaria cultivars tested.

The large difference in yield between farms for a given cultivar was attributed to farmers' failure to follow recommended agronomic practices such as proper plant spacing, lack of weeding at establishment, limited use of fertilizer, etc. Generally, where the yields were poor the grasses were established in eroded and less fertile part of farm and no fertilizer application. In contrast in farms where the yields were high, the land was well terraced, and farmer had adopted proper soil conservation practices. Additionally, farmers had applied either cattle manure or inorganic fertilizer or both. The higher yield achieved in Kirinyaga was attributed to more rainfall experienced from June to October unlike in Kangundo where there was no rains resulting in the cessation of plant growth. 
Table 5 Mean DM yield among the Brachiaria grass cultivars in Kirinyaga and Kangundo study sites

\begin{tabular}{|c|c|c|c|}
\hline \multirow[b]{2}{*}{ Brachiaria grass cultivars } & Kirinyaga & Kangundo & \multirow{2}{*}{$\begin{array}{l}\text { LSD } \\
(p<0.05)\end{array}$} \\
\hline & \multicolumn{2}{|c|}{ DM yield (kg/ha) } & \\
\hline $\begin{array}{l}\text { Brachiaria decumbens } \mathrm{cv} . \\
\text { Basilisk }\end{array}$ & $\begin{array}{l}6702(1704- \\
18,156)\end{array}$ & $\begin{array}{l}5485(1081- \\
12,204)\end{array}$ & N.S. \\
\hline Brachiaria brizantha cv. Piata & $\begin{array}{l}6884(2548- \\
15,363)\end{array}$ & $\begin{array}{l}6447(3510- \\
10,922)\end{array}$ & N.S. \\
\hline Brachiaria brizantha cv. Xaraes & $\begin{array}{l}5108(1733- \\
12,962)\end{array}$ & $\begin{array}{l}5680(1175- \\
12,856)\end{array}$ & N.S. \\
\hline $\operatorname{LSD}(\mathrm{p}<0.05)$ & N.S. $^{a}$ & N.S. & \\
\hline
\end{tabular}

Values in parenthesis are range of DM yield

${ }^{a}$ N.S. not significant

\section{Box 1}

Effects of Brachiaria forage on social-economic conditions: By August 2019 approximately 1320 smallholder farmers (18.2\% females) mainly involved in dairy cattle farming had been provided with Brachiaria grass seeds in Kirinyaga County. In Kangundo, 720 smallholder farmers (23\% were females) received the seeds. Report from field indicates that each farmer has given out splits to at least two other farmers. Conservative estimate put the numbers of farmers to over $\mathbf{4 0 0 0}$ farmers implying a high rate of uptake of the technology in the project areas. Seeds were also distributed to 1200 farmers in Nyeri County and over $\mathbf{3 0 0}$ farmers in other parts of Kenya. So far, the project has not found any farmer who has abandoned growing Brachiaria. Farmers are enthusiastic about the grass, and a good number have expanded the acreage under Brachiaria grass. Farmers have also reported increase in milk production from dairy cattle fed Brachiaria grasses. However, there were variation in terms increase, but the values were within the range of $15-40 \%$ recorded by Muinga et al. (2016). This implies Brachiaria has contributed to increased milk availability for consumption at household level and for sale to generate income. However, there are plan to carry out on-farm feeding trial jointly with farmers to ascertain the actual benefits of Brachiaria in term of milk production. In Kirinyaga, youths have formed groups with aim of baling Brachiaria hay for sale to generate income. (Source: Field Survey)

\section{Participatory Selection of Brachiaria Grass Cultivars}

During the FGD, farmers identified 16 plant attributes that are important when selecting grasses (Table 6). Grasses that give high milk yield when fed to livestock were ranked first followed by highly nutritious grasses while color was the least important criteria. These findings were consistent with earlier work carried 


\begin{tabular}{|c|c|c|c|c|c|c|c|c|c|c|}
\hline & If & $\simeq$ & $\bar{D}$ & $a$ & in & $\underline{\vec{\omega}}$ & $\overrightarrow{\widetilde{N}}$ & 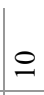 & $\stackrel{-}{\circ}$ & $=$ \\
\hline & -0 & $\nabla$ & $\simeq$ & $r$ & $=$ & 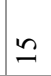 & \pm & r & 0 & 0 \\
\hline & $\underline{\mathbf{I}}$ & $\hat{\widehat{\theta}}$ & Оี & 鱼 & $\stackrel{\approx}{a}$ & 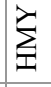 & 主 & $\underline{\underline{1}}$ & 全 & $\widehat{\underline{1}}$ \\
\hline & $\sum_{I}$ & $\sum_{I I}$ & 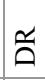 & $\sum_{I I}$ & $\approx$ & $\sum_{1}$ & 疍 & $\sum_{I I}$ & $\sum_{i=1}$ & $\sum_{I I}$ \\
\hline
\end{tabular}

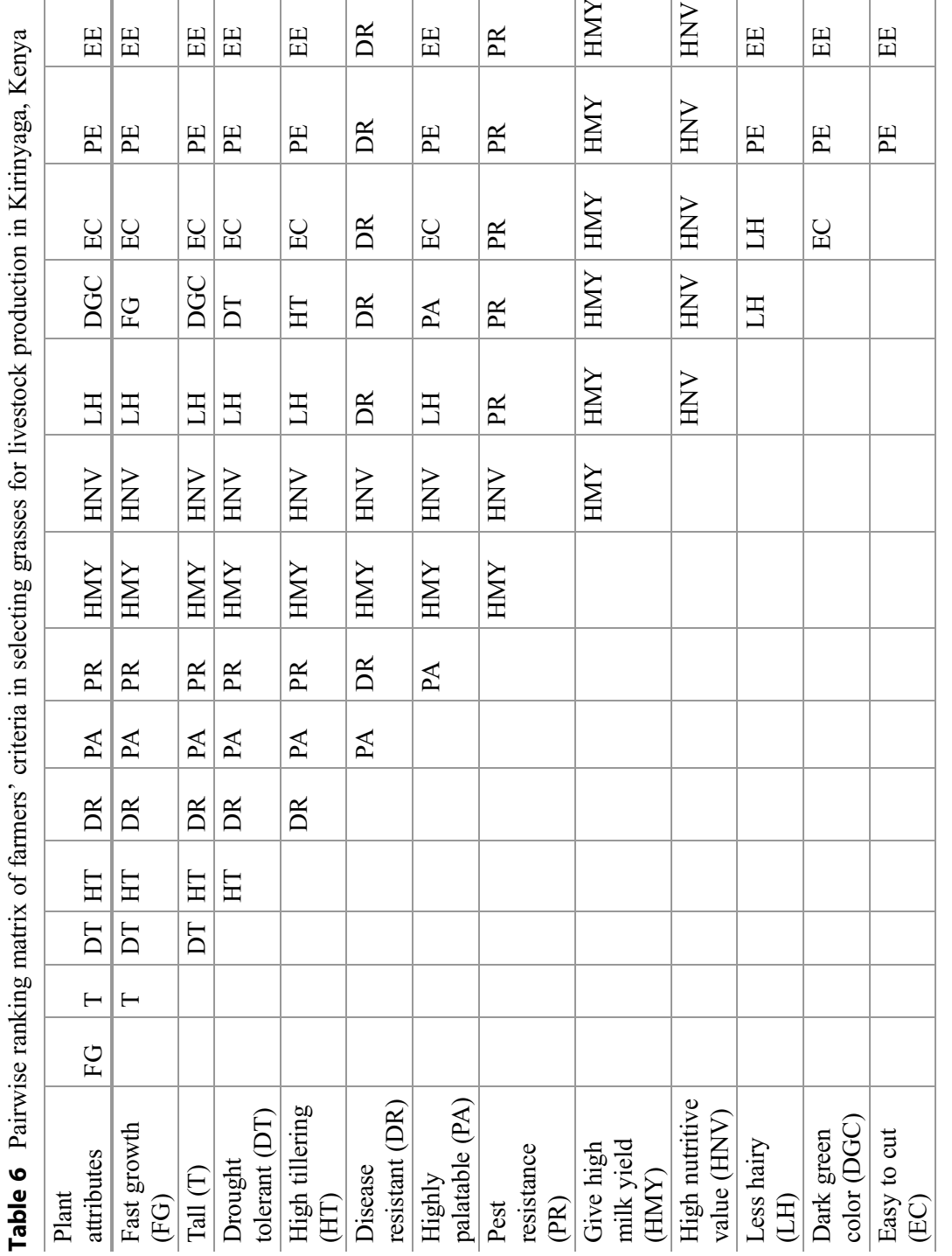




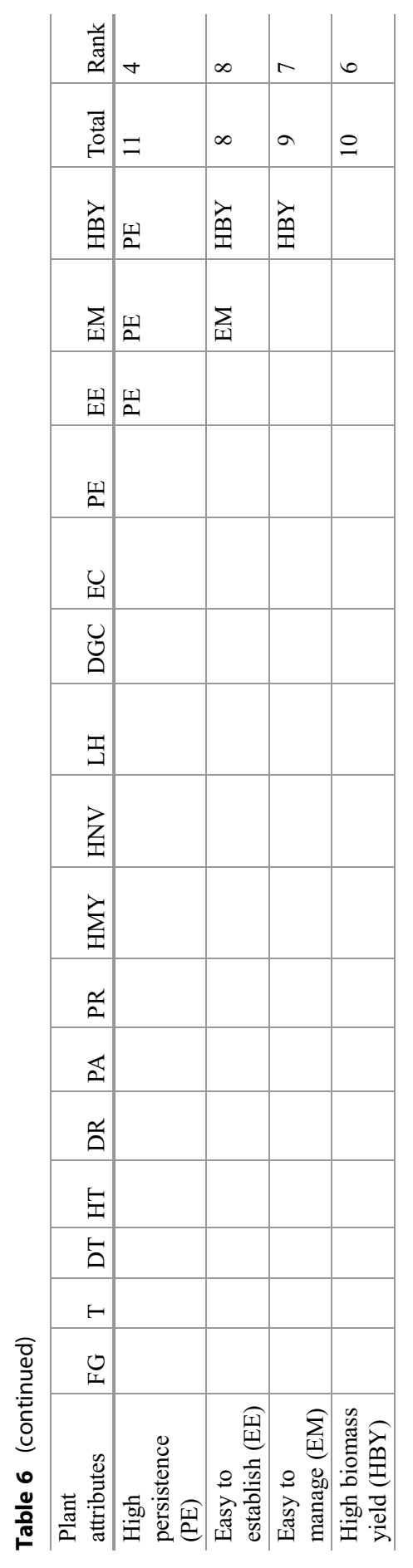


elsewhere in Kangundo by Gatheru et al. (2016). They reported that forages that gave high milk yield when fed to cattle and nutritionally balanced were priority traits in selecting feed for livestock. There were significant differences $(p<0.05)$ in farmers' scores for herbage, tillers, and tallness between the cultivars (Table 7). Overall, Basilisk had the highest mean score for the five attributes followed by MG-4, while Piata had the lowest. There were no significant differences on farmers' scores for hairiness and ease of cutting between the cultivars. The ranking order for the cultivars was not different between females and male farmers (Fig. 4).

Table 7 Farmers' mean scores for selected criteria from evaluation of Brachiaria cultivars

\begin{tabular}{|c|c|c|c|c|c|c|c|}
\hline \multirow[b]{2}{*}{$\begin{array}{l}\text { Grass } \\
\text { cultivars }\end{array}$} & \multicolumn{5}{|c|}{ Selection criterion } & \multirow[b]{2}{*}{$\begin{array}{l}\text { Mean } \\
\text { score }\end{array}$} & \multirow[b]{2}{*}{ Rank } \\
\hline & $\begin{array}{l}\text { Herbage } \\
\text { production }\end{array}$ & $\begin{array}{l}\text { Tillering } \\
\text { capacity }\end{array}$ & $\begin{array}{l}\text { Height at } \\
\text { harvest }\end{array}$ & Hairiness & $\begin{array}{l}\text { Easy } \\
\text { to cut }\end{array}$ & & \\
\hline Basilisk & 3.40 & 3.36 & 3.23 & 2.66 & 3.28 & 3.19 & 1 \\
\hline MG-4 & 3.19 & 3.19 & 2.70 & 2.99 & 3.09 & 3.03 & 2 \\
\hline Piata & 2.32 & 2.49 & 2.00 & 2.67 & 3.01 & 2.50 & 5 \\
\hline Xaraes & 2.63 & 2.79 & 2.21 & 2.99 & 3.12 & 2.75 & 3 \\
\hline $\begin{array}{l}\text { Rhodes } \\
\text { grass }\end{array}$ & 2.16 & 1.85 & 3.13 & 2.97 & 3.03 & 2.63 & 4 \\
\hline $\begin{array}{l}\text { LSD } \\
(\mathrm{p}<0.05)\end{array}$ & 0.31 & 0.29 & 0.29 & N.S. ${ }^{a}$ & N.S. & & \\
\hline
\end{tabular}

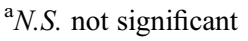

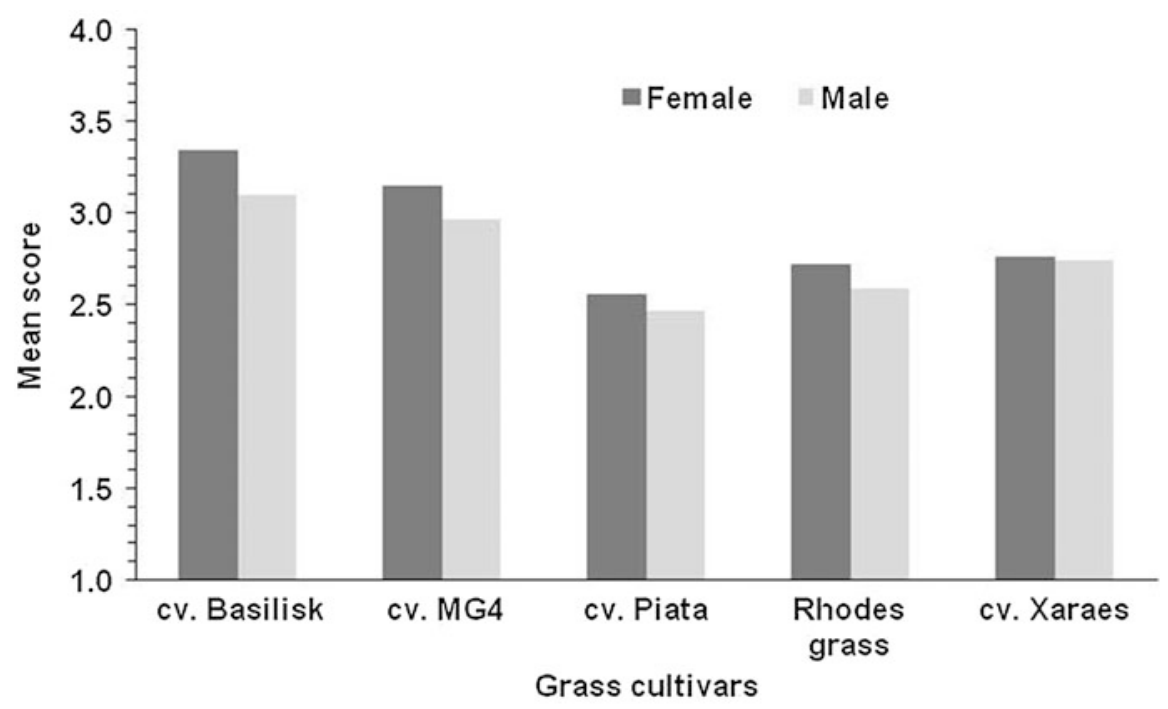

Fig. 4 Evaluation score for Brachiaria grass cultivars and Rhodes grass categorized by gender 


\section{Upscaling Brachiaria Grasses Cultivars}

Multi-actor Platform: The multi-actor platform (MAP) members are composed from institution in private sectors, policy makers, dairy cooperative societies, extension services, farmers, and researchers. The MAP members were involved at InnovAfrica project inception phase during planning, site selection, and development of implementation framework. The MAPs have contributed in Brachiaria grass validation trial particularly in selection of farmers and development of selection criteria. They participate in field project evaluation and monitoring every 6 months and provide useful feedback to correct any divergence from the planned activities. They are also involved in upscaling of Brachiaria grass technologies through field days and distribution of seeds. For example, one MAP member who is committee of Mukurwe-ini Wakulima Dairy Cooperative Society has distributed seeds to over 1200 farmers who are members of the society in Nyeri County.

Village knowledge Centre: One VKC was established in Kangundo village of Kangundo subcounty in May 2018. From May 2018 to December 2019, a total of 530 people (comprising of farmers, extension agents the public sector, and nongovernmental organization) and other stakeholders visited the VKC (Fig. 5) primarily to get information on Brachiaria grasses and on other issues (e.g., horticulture, poultry, bee, rabbits, microfinance). Most of the visitors to the $\mathrm{VKC}$ were over 50 years old. The VKC has connected over 300 farmers on social media (two WhatsApp Group). These have provided a platform where information on cultivation of Brachiaria grass including management, conservation, and feeding is shared. However, social networking is an important mean for promoting technology adoption (Brhane et al. 2019).

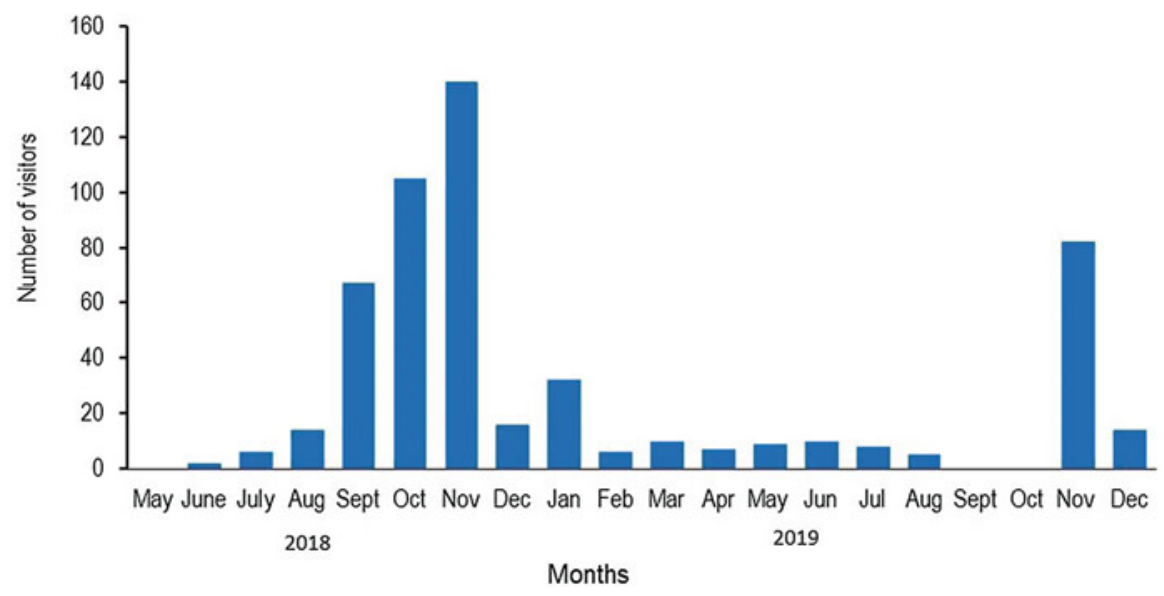

Fig. 5 Number of visitors to the Village Knowledge Centre from May 2018 to December 2019 in Kangundo, Kenya 


\section{Box 2 Other Brachiaria Upscaling Strategies Adopted}

Field days: In May 2018, a farmer field day was held in Kangundo village to provide first-hand information to farmers and relevant stakeholders on Brachiaria-livestock value chain and related technologies and its impact on the feed security and livestock productivity. A total of 93 people representing smallholder dairy farmers, members of a small-scale dairy processing group, County extension agents, local leaders, and InnovAfrica partners attended.

Agricultural show and exhibition: InnovAfrica project participated in Agricultural Show of Kenya (ASK), Machakos Branch, in June 2018 and 2019 to create awareness on the Brachiaria technologies. The grasses were planted in small plots within the ASK ground for exhibition to farmers. Posters with details on the establishment, management, and nutritive quality of the grasses were also displayed. In 2018 an estimated 770 show attendants (farmers, scholars, and students) visited the Brachiaria grass plots, and the number increased to 1050 in 2019.

Posters: The project has also adopted posters to create farmer awareness on the availability of Brachiaria grass seeds for planting. Over 550 and 770 posters written in vernacular were distributed in Kirinyaga County and Kangundo subcounty, respectively. The posters were displayed at strategic locations where they were easily visible. This included trees along rural roads, in market centers, petrol stations, churches, dairy cooperatives, premises, and other public buildings where the local people visit frequently.

Agricultural Training Centre: The project has partnered with Kamweti ATC and Wambugu ATC in Kirinyaga and Nyeri Counties, respectively, to accelerate the upscaling of Brachiaria grass technology. These Centers normally organize field days, trains farmers, and conduct demonstrations on proven technologies on crops, forages, and livestock. The role of the ATCs is to bulk the Brachiaria grass and distribute splits to farmers.

\section{Conclusions and Way Forward}

This study is a farmer led experimentation to test Brachiaria grass for livestock production in Kirinyaga County and upscaling it in Kangundo subcounty. The validation trial showed that all the Brachiaria grass cultivars were more productive than the control (Rhodes grass) in most of the harvests. Similarly, based on phenotypic traits used by farmers to evaluate the grass, all the Brachiaria grass cultivars had higher mean score than Rhodes grass. Thus, Brachiaria has a potential to improve the feed availability in the region tested and other areas of Kenya and enhance food and nutrition security. The org $\mathrm{C}$ contents in the Brachiaria fields will improve the organic matter content of the soils which in turn will enhance soil fertility and increase productivity. This makes Brachiaria grass suitable for use in 
adaptation and mitigation measures to climate change effects in Kenya and possibly in other SSA countries. Over 4000 farmers are now engaged in cultivation Brachiaria grass in the study sites and additional 1500 farmers in other parts of Kenya, because of increased awareness by the InnovAfrica project using innovative EASs including VKC, ASK, posters, social media, and MAPs engagement. The demand for Brachiaria seeds is increasing due to benefits gained in terms of increased milk from livestock fed on the grass. Nevertheless, there is need to continue to upscale Brachiaria grass using already existing avenues and/or establish new ones.

Acknowledgements This is funded by the European's Union H2020, research and innovation program under Grant Agreement No. 727201.

\section{References}

Association of Official Analytical Chemists (AOAC) (1990) Official methods of analysis of the AOAC, 15th edn. AOAC, Arlington, pp 1-1298

Bremner JM, Keeney DR (1965) Steam distillation methods for determination of ammonium, nitrate and nitrite. Anal Chem Acta 32:485-495

Brhane G, Fantaye Belay F, Gebreselassie T, Desta D (2019) Enhancing sorghum yield through demonstration of improved sorghum varieties in Tanqua-Abergelle Wereda, Central Zone of Tigray, Ethiopia. J Agric Ext Rural Dev 11:11-16. https://doi.org/10.5897/JAERD2018.1020

Christensen NJH, Hewitson B, Busuioc A, Chen A, Gao X, Held I, Jones R, Kolli RK, Kwon W-T, Laprise R, Magana Rueda V, Mearn SL, Menendez CG, Raisanen J, Rinke A, Sarr A, Whetton P (2007) Chapter 11: Regional climate projections. In: Climate change 2007: the physical science basis. Contribution of working group I to the Fourth Assessment Report of the Intergovernmental Panel on Climate Change. Cambridge University Press, Cambridge, pp 847-940

Djikeng A, Rao IM, Njarui D, Mutimura M, Caradus J, Ghimire SR, Johnson L, Cardoso JA, Ahonsi M, Kelemu S (2014) Climate-smart Brachiaria grasses for improving livestock production in East Africa. Trop Grassl-Forrajes Trop 2(1):38-39

Freier KP, Bruggemann R, Scheffran J, Finckh M, Schneider UA (2012) Assessing the predictability of future livelihood strategies of pastoralists in semi-arid Morocco under climate change. Technol Forecast Soc Chang 79(2):371-382

Gatheru M, Njarui DMG, Gichangi EM (2016) Participatory evaluation and selection of suitable Brachiaria grass cultivars for production in the semi-arid eastern Kenya. In: Njarui DMG, Gichangi EM, Ghimire SR, Muinga RW (eds) Climate smart Brachiaria grasses for improving livestock production in East Africa - Kenya experience. Proceedings of the workshop held in Naivasha, Kenya, 14-15 Sept 2016. Nairobi, pp 124-131

Ghimire S, Njarui D, Mutimura M, Cardoso J, Johnson L, Gichangi E, Teasdale S, Odokonyero K, Caradus J, Rao I, Djikeng A (2015) Climate-smart Brachiaria for improving livestock production in East Africa: emerging opportunities. In: Vijaya D, Srivastava M, Gupta C, Malaviya D, Roy M, Mahanta S, Singh J, Maity A, Ghos P (eds) Sustainable use of grassland resources for forage production, biodiversity and environmental protection. Proceedings of 23rd International Grassland Congress, 20-24 Nov 2015, New Delhi, pp 361-370

Jaetzold R, Schmidt H, Hornetz B, Shisanya C (2006) Farm management handbook of Kenya, vol. II: natural conditions and farm management information. Part C: East Kenya Subpart C2 Coast Province, 2nd edn. Ministry of Agriculture and GIZ, Nairobi

Keating BA, Siambi MN, Wafula BM (1992) The impact of climatic variability on cropping research in semi-arid Kenya between 1955 and 1985. In: Probert ME (ed) A search for strategies 
for sustainable dryland cropping in semi-arid Eastern Kenya. ACIAR proceedings no. 41, Canberra, pp 16-25

Kenya National Bureau of Statistics (KNBS) (2010) The 2009 Kenya population and housing census: vol. II: population and household distribution by socio-economic characteristics. Kenya National Bureau of Statistics, Nairobi, p 438

Kusewa P, Guiragossion V (1989) Research priorities for enhancing crop productivity in marginal areas of Kenya. In: Agricultural research in Kenya, achievements, challenges and prospects. Proceedings of the 1st KARI scientific conference held at Panafric Hotel Kenya, 14-16 Aug 1989, pp 21-36

Laidlaw A (2005) The relationship between tiller appearance in spring and contribution of drymatter yield in perennial ryegrass (Lolium perenne L.) cultivars differing in heading date. Grass Forage Sci 60:200-209

Lusweti CM, Nandasaba J, Onginjo E, Asena D (2004) Preliminary results of disease survey on Napier grass in selected sites of Western Kenya. Pasture research annual report 2004. National Agricultural Research Centre, Kitale

Martin R, Linstädter A, Frank K, Müller B (2016) Livelihood security in face of drought - assessing the vulnerability of pastoral households. Environ Model Softw 75:414-423

Muinga RW, Njunie MN, Gatheru M, Njarui DMG (2016) The effects of Brachiaria grass cultivars on lactation performance of dairy cattle in Kenya. In: Njarui DMG, Gichangi EM, Ghimire SR, Muinga RW (eds) Climate smart Brachiaria grasses for improving livestock production in East Africa - Kenya experience. Proceedings of the workshop held in Naivasha, Kenya, 14-15 Sept 2016. Nairobi, pp 229-237

Ngila P, Njarui DM, Musimba NK, Njunie MN (2016) Performance of Galla goats fed different cultivars of Brachiaria in the coastal lowlands of Kenya. J Fish Livest Prod 5:210. https://doi. org/10.4172/2332-2608.1000210

Njarui DMG, Gichangi EM, Ghimire SR, Muinga RW (eds) (2016) Climate smart Brachiaria grass for improving livestock production in East Africa - Kenya experiences. Kenya Agricultural and Livestock Research Organization, Nairobi, p 271. https://cgspace.cgiar.org/handle/10568/79797

Nyambati EM, Ayako W, Mailu S, Chelimo EJ, Njarui DMG (2016) Production and nutritive quality of Brachiaria grass cultivars subjected to different cutting intervals in the cool sub-humid highlands of central Kenya. In: Njarui DMG, Gichangi EM, Ghimire SR, Muinga RW (eds) Climate smart Brachiaria grasses for improving livestock production in East Africa - Kenya experience. Proceedings of the workshop held in Naivasha, Kenya, 14-15 Sept 2016. Nairobi, pp 62-69

Okalebo JR, Gathua KW, Woomer PL (2002) Laboratory methods of soil and plant analysis: a working manual, 2nd edn. TSBF-CIAT and SACRED Africa, Nairobi, p 128

RoK (Republic of Kenya) (2019) Ministry of Agriculture, Livestock, Fisheries and Irrigation, State Department for livestock. Draft National Livestock Policy, Kenya, p 75

Schilling J, Freier KP, Hertig E, Scheffran J (2012) Climate change, vulnerability and adaptation in North Africa with focus on Morocco. Agric Ecosyst Environ 156:12-26

Simpson JR, Okalebo JR, Lubulwa G (1996) The problem of maintaining soil fertility in Eastern Kenya. A review of relevant research. ACIAR monograph no. 41, Canberra, p 60

Thornton PK, van de Steeg J, Notenbaert A, Herrero M (2009) The impacts of climate change on livestock and livestock systems in developing countries: a review of what we know and what we need to know. Agric Syst 101:113-127

Van Soest PJ, Robertson JD, Lewis BA (1991) Methods for dietary fibre, neutral detergent fibre and non-starch polysaccharides in relation to animal nutrition. J Dairy Sci 74:3583-3597

VSN International Ltd (2013) Genstat for windows, 15th edn. VSN International Ltd, Hemel Hempstead

Watanabe FS, Olsen SR (1965) Test of an ascorbic acid method for determining phosphorus in water and sodium bicarbonate extracts from soils. Soil Sci Soc Am J 29:677-678

World Bank (2013) Turn down the heat: climate extremes, regional impacts, and the case for resilience - a report for the World Bank by the Potsdam Institute for Climate Impact Research and Climate Analytics. World Bank, Washington, DC, p 254 
Open Access This chapter is licensed under the terms of the Creative Commons Attribution 4.0 International License (http://creativecommons.org/licenses/by/4.0/), which permits use, sharing, adaptation, distribution and reproduction in any medium or format, as long as you give appropriate credit to the original author(s) and the source, provide a link to the Creative Commons license and indicate if changes were made.

The images or other third party material in this chapter are included in the chapter's Creative Commons license, unless indicated otherwise in a credit line to the material. If material is not included in the chapter's Creative Commons license and your intended use is not permitted by statutory regulation or exceeds the permitted use, you will need to obtain permission directly from the copyright holder.

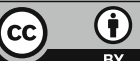

